\title{
Determinant Factors for the Spread of COVID-19 Virus into African Countries: Cross Sectional Data Analysis
}

Tesfaye Eresso Gofe ${ }^{1,}$ *, Tarekegn Tariku Ebissa ${ }^{1}$, Dugasa Rafisa Olan ${ }^{1}$, Firidisa Biru Goshu ${ }^{2}$, Alemayehu Mebre Niway ${ }^{1}$, Mulunesh Teferi Merga ${ }^{1}$, Hana Desalegn Geleta ${ }^{1}$, Dinkinesh Bedasa Beyene ${ }^{1}$, Melkam Adam Abdela ${ }^{3}$, Meraba Atomsa Ayana ${ }^{1}$, Damu Fayera Gina ${ }^{1}$, Kebene Bekele Hordofa ${ }^{1}$, Alemi Habte Nemera ${ }^{1}$, Kabtamu Cheru Fentik ${ }^{1}$, Tariku Tufa Garedew ${ }^{1}$, Zara Kemal Bashir ${ }^{1}$, Shibiru Ketema Abasimbo ${ }^{1}$, Lemi Tiyar Kuma ${ }^{1}$

${ }^{1}$ Accounting and Finance Department, Wollega University, Nekemte, Ethiopia

${ }^{2}$ Economic Department, Wollega University, Nekemte, Ethiopia

${ }^{3}$ Management Department, Wollega University, Nekemte, Ethiopia

Email address:

tesfaye.eresso@yahoo.com (T. E. Gofe)

${ }^{*}$ Corresponding author

\section{To cite this article:}

Tesfaye Eresso Gofe, Tarekegn Tariku Ebissa, Dugasa Rafisa Olan, Firidisa Biru Goshu, Alemayehu Mebre Niway, Mulunesh Teferi Merga, Hana Desalegn Geleta, Dinkinesh Bedasa Beyene, Melkam Adam Abdela, Meraba Atomsa Ayana, Damu Fayera Gina, Kebene Bekele Hordofa, Alemi Habte Nemera, Kabtamu Cheru Fentik, Tariku Tufa Garedew, Zara Kemal Bashir, Shibiru Ketema Abasimbo, Lemi Tiyar Kuma. Determinant Factors for the Spread of COVID-19 Virus into African Countries: Cross Sectional Data Analysis. Humanities and Social Sciences. Vol. 9, No. 2, 2021, pp. 45-50. doi: 10.11648/j.hss.20210902.12

Received: January 14, 2021; Accepted: March 17, 2021; Published: April 12, 2021

\begin{abstract}
The Novel Coronavirus pandemic is a global challenge that requires coordinated efforts from governments, individuals, businesses, and various stakeholders. The main aim of this study is to investigate factors contributing to the spread of COVID-19 virus into African countries. OLS regression model was adopted to identify the major determinants - were categorized as social, economic and political factors. Confirmed cases as COVID-19 virus infection was the dependent variable. The data was obtained from websites of internationally recognized organizations for the corresponding African countries included in the study. The study was focused on 53 African countries these have full data at the time of its collection. The findings of the study revealed that population size, net migration rate, airways passengers and internet penetration rate have significant and positive contribution to the spread of COVID-19 coronal virus regardless of the country's population density, population below the poverty line, unemployment rate, literacy rate, press freedom index, global peace index, sub-region and gross domestic product. Thus, Social and economic factors were more significant than political factors for the spread of COVID-19 virus. It is better if policy and controlling mechanisms are designed regarding to the country's degree of population size, net migration rate, internet penetration rate, and number of airways passengers to slowdown the spread of COVID-19 virus in African countries.
\end{abstract}

Keywords: COVID-19 Spread, Corona Virus, Africa, Social, Economic, Political Factors, Ethiopia

\section{Introduction}

The Novel Coronavirus pandemic is a global challenge that requires coordinated efforts from governments, individuals, businesses, and various stakeholders. The novel human coronavirus (COVID-19) outbreak is currently continued to spread across the world and has been declared as pandemic by World Health Organization on 11, March 2020 and has been became a global emergency, given its impact on the entire World population and the economy [9]. The first confirmed COVID-19 case in Africa was reported in Egypt on February 14, 2020 and since then the number of confirmed infections in the region kept increasing and has surpassed over 5000 cases by March 31, 2020 [9]. According to the Johns Hopkins University report, as of September 17, 2020 , there have been $6,632,689$ total confirmed cases of COVID-19 virus in the world and more than 1.3 million total confirmed cases in Africa. 
Upon appearance of COVID-19, several studies have examined the transmission dynamics of the pandemic. While some have documented the route of transmission through human-to-human contact, others have examined the role that some environmental factors may play in facilitating the rate of spread of the virus through the analysis of temporal and spatial relationships of these factors with COVID-19 transmission rate. Most of these studies have reported a significant relationship between transmission rate and several proxies of temperature and humidity, suggesting that the disease spread is enhanced in colder and drier climates [11].

However, other social, economic and political variables have been received less attention and the findings are inconclusive or differed among countries. Overall, despite the rapid response of the scientific community to understand the transmission of COVID-19 virus, the role that environmental variables play in the disease dynamics remains an open question that requires further evidence across the world. Even though the pandemic is spreading vastly around the globe and especially in African continent, still there is no clear justification for the rapidly spread of COVID-19 virus in African countries. Henceforth, this study intends to investigate determinant factors for the spread of the COVID19 virus into African countries.

\section{Statement of the Problem}

As we know, societies around the world are struggling to protect their populations from the COVID-19 pandemic. Both citizens and policymakers are trying to make sense of the magnitude of the crisis and the lives that it threatens. Given the current trends in incidence and underlying healthcare systems vulnerabilities, Africa could become the next epicenter of the COVID-19 pandemic [9]. Much remains unknown about the trajectory of the transmission of COVID-19 in Africa. Many fear that with its high levels of poverty, weak health systems, and crowded urban areas, the virus could be particularly devastating. Others hope that with its warmer climate, youthful population, and experience fighting infectious disease, that Africa will be able to avoid the worst of the pandemic. Several studies have examined the transmission dynamics of the novel coronavirus in different parts of the world. Some have reported relationships with several environmental variables, suggesting that spread of the disease is enhanced in colder and drier climates. However, evidence is still scarce and mostly limited to a few countries, particularly from the Africa point of view. This study intends to investigate determinant factors for the spread of COVID-19 virus into African countries. The study investigated the determinant factors in terms of three broad variables such as social, economic and political factors.

\section{Research Questions}

The following research inquiries were answered by this study.

1. Does social factor contributes to the spread of COVID-
19 into African countries?

2. How economic facts determine the spread of COVID19 into African countries?

3. Does political factor contributes to the spread of COVID-19 into African countries?

\section{Objective of the Study}

The main objective of this study was to investigate the determinant factors for the spread of COVID-19 virus in to African countries by taking 53 countries in the continent. Specifically, the study was conducted to investigate the social, economic and political factors contributing to the spread of COVID-19 virus into African countries.

\section{Related Literature Review}

African Union in its report on "impact of the corona virus (COVID-19) on African economy" stated that because of its openness to international trade and migration, Africa is not immune to the harmful effects of COVID-19, which are categorized as indigenous and exogenous effects [10].

These factors considered as social factors include total population, population density, population below poverty line; life expectancy and net migration rate. Countries with higher population size have higher chance to be exposed to COVID19 virus. "According to Kushan Tharuka Lulbadda et al. [5] population size, temperature, and median age are positively associated with the spreading rate of COVID-19. The study conducted to assess the potential impact of COVID-19 on life expectancy [6] argued that COVID-19 would not affect life expectancy substantially as long as the COVID-19 infection prevalence rate remains below 1 or $2 \%$. However, with $50 \%$ prevalence of COVID-19 infections, life expectancy would drop by 2 to 9 years in various areas of the globe. And the study undertaken by Sirkeci, I., \& Yucesahin, M. M. argued that, the volume of migration in each migration corridor linking the countries of origin and destination appears as a strong indicator for the spread of the pandemic [7].

Countries' gross domestic product (GDP), unemployment rate, air transport passengers and internet penetration rate were included in the economic factors. The assessment conducted by Grace Gondwe [2] on the impact of COVID-19 on Africa's economic development estimated that African economies will fall by $1.4 \%$ in GDP and the newly released study on impacts of covid-19 on labor market and poverty in South Africa shows a $40 \%$ decline in active employment [4].

Following the movement of people along busy commercial and touristic routes, COVID-19 has initially affected African countries. The virus has emerged in a world tightly connected by local and international population movements, with more people moving for work, education and family reasons, tourism and survival than ever in the past [8] "Intense population movements, in particular of tourists and business workers, have been a key driver of the global spread of the outbreak" [3].

The press freedom index, global peace index and sub- 
region of a given country were included in political factors Effective communication, especially during severe crisis and risk is essential in developing countries to reduce panic levels and the number of infections during pandemics including COVID-19. The risks of miscommunication during the COVID-19 pandemic are undoubtedly high and recommended for existence of the effective crisis and risk communication that will help to build trust, creditable, honest, transparent and accountable source of information [1].

The report posted by Africa Center for Strategic Studies states the advantageous of free press and media. They serve as irreplaceable warning system for a society at the time of emergency by sharpening focus on the severity of a problem; prompting an urgent government response; validating government pronouncements; making government accountable for transparent reporting of key data and forcing the government narrative to mirror reality. The study conducted in India to investigate the impacts of geographical factors to the COVID-19 outbreak suggested that geographical factors like climate have an unavoidable influence on viral spread of the pandemic.

\section{Research Design and Methodology}

In line with the aim of the study, quantitative research design and OLS regression model were adopted. Secondary data was collected for analysis and obtained from the websites of various recognized international entities like World Bank, WHO, AU, African CDC center and other online data providers. The data were collected from the websites for 53 African countries and the remaining countries were excluded due to absence of full data and annual report for the respective country.

Dependent and Independent Variables

The number of cases confirmed as COVID-19 virus infection was the dependent variable in this study. The independent variable involves twelve other factors such as a country's total population, population density, population below the poverty line, net migration rate, unemployment rate, literacy rate, internet penetration rate, press freedom index, number of airways passengers, global peace index, sub-region and GDP of respective country. These variables were grouped as social, economic and political factors. Data for all of these variables were obtained from webpages of World Bank, Africa Union, Africa CDC center and index mundi thematic map.

Model specification

The ordinary least square (OLS) regression model was employed to investigate the determinant factors for the spread of COVID-19 virus to African countries. The model was formulated as:

$$
\begin{aligned}
\ln \text { COVID-19 } & =\beta_{0}+\beta_{1} \operatorname{lnPopu}+\beta_{2} \text { InPopuDens }+\beta_{3} \text { PBelowpv }+\beta_{4} \text { Netmigra }+\beta_{5} \text { UnempRate }+\beta_{6} \text { Literacy } \\
& +\beta_{7} \text { InternetPen }+\beta_{8} \text { PressFreed }+\beta_{9} \text { AirTrans }+\beta_{10} \text { GPeace }+\beta_{11} \text { Subregion }+\beta_{12} \operatorname{lng} \text { dp }+\varepsilon_{i}
\end{aligned}
$$

Where:

lnCOVID-19 = the natural logarithm of number of cases confirmed as COVID-19 virus infection.

$\operatorname{lnPopu}=$ the natural logarithm of total population of a country

$\ln$ PopuDens $=$ the natural logarithm of a country's population density

PBelowpv $=$ the number of population below the poverty line

Netmigra $=$ net migration rate

UnempRate $=$ unemployment rate of a country

Literacy $=$ literacy rate

InternetPen $=$ internet penetration rate

PressFreed $=$ press freedom index

AirTrans $=$ number of passengers via airways

GPeace $=$ global peace index of a country

Sub-region $=$ the regional category of a country (represented as Eastern $=1$, Western $=2$, Northern $=3$, Southern $=4 \&$ Middle $=5$ )

$\operatorname{lngdp}=$ the natural logarithm of gross domestic product of a country

$\epsilon=$ error term

\section{Data Analysis and Discussion}

As it was mentioned in the research methodology section, OLS regression model is employed to investigate and analyze the main determinant factors for the spread of
COVID-19 virus to different African countries. The data used in this analysis and investigation were collected from 53 African countries. Other African countries were excluded from the study due to the absence of full data about the countries.

The latest raw data related to the number of confirmed cases as COVID-19 virus infection in African countries was accessed on September 17, 2020 from Worldometers [10] daily report. The total confirmed cases as COVID-19 virus infection in Africa was 1,380,233 at the time of data collection. The number of death was 33,308 while $1,131,194$ were recovered from the virus according to the worldometers report.

OLS Assumptions

As it was mentioned in the model specification section, OLS regression model was adopted to investigate the determinant factors for the spread of COVID-19 into African countries. However, certain assumptions of OLS regression should be met for its implementation. In this section the OLS assumptions for multicollinearity, normality and heteroscedasticity were diagnosed. The diagnostic test for multicollinearity assumption was performed by running Variant Inflation Factors (VIF) after excluding the dummy variable (i.e., sub-region) from the regression as the outcome is presented below.

Variance inflation factor 
Table 1. Variance inflation factor.

\begin{tabular}{lll}
\hline & VIF & 1/VIF \\
\hline Lngdp & 3.596 & 0.278 \\
lnPopu & 3.558 & 0.281 \\
GPeace & 2.333 & 0.429 \\
AirTrans & 2.219 & 0.451 \\
UnempRate & 2.202 & 0.454 \\
InternetPen & 1.889 & 0.529 \\
Literacy & 1.858 & 0.538 \\
lnPopuDens & 1.857 & 0.539 \\
PBelowpv & 1.738 & 0.575 \\
PressFreed & 1.596 & 0.627 \\
Netmigra & 1.238 & 0.808 \\
\hline
\end{tabular}

The result shows the absence of serious multicollinearity problem across all variables since the VIF value of all variables is less than 10. Likewise the diagnostic test for normality was made using histogram and almost the residuals were normality distributed.

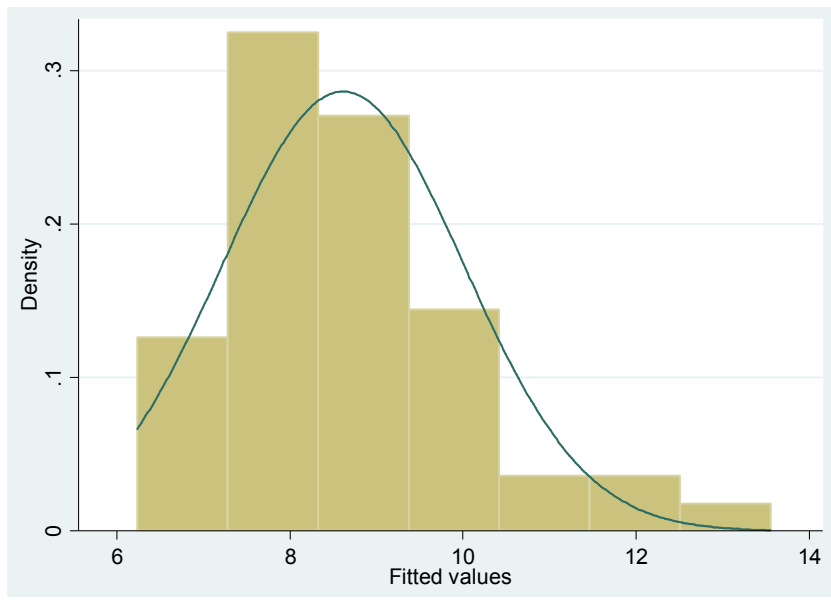

Figure 1. Normality Test.
The assumption tests for heteroscedasticity was made by running Breusch-Pagan/Cook-Weisberg test for heteroskedasticity and the hypothesis for presence of heteroscedasticity in the data was rejected because the hypothesis result is insignificant.

Breusch-Pagan / Cook-Weisberg test for heteroskedasticity Ho: Constant variance Variables: fitted values of 1 COVID19 chi2 $(1)=0.40$ Prob $>$ chi $2=0.5295$

The assumption test for autocorrelation was not conducted in this study because the problem for the presence of autocorrelation is not substantial in cross sectional data.

On the other hand, the regression outcomes run on STATA v14 are presented below in table 1 . The model is highly significant at $1 \%$ significant level $(\mathrm{p}=000)$ and the contributing factors for the spread of COVID-19 were explained up to $72.25 \%$ (R-squared $=0.7225)$ by this model which indicates the presence of good model fit. As the regression outcomes indicate, four of the independent variables, namely population size, net migration rate, internet penetration rate and number of air ways passengers were contributing significantly to the spread of COVID-19 virus to African countries. However, other variables have no direct and significant contribution to the spread of COVID-19 virus. The analysis and interpretation for the significant factors are presented below.

First, the total population level of a country has positive and significant $(\beta=0.3878, \mathrm{p}=0.026)$ contribution to the spread of COVID-19 virus to African countries at $5 \%$ significant level regardless of the country's economy GDP. Most pulpous countries have high exposure for the spread of the pandemic than less populated countries. One person increase in population contributes about $38.78 \%$ for the spread of COVID-19 to African countries.

Table 2. Regression outcomes.

\begin{tabular}{|c|c|c|c|c|c|c|c|}
\hline InCOVID-19 & Coef. & St.Err. & t-value & p-value & {$[95 \%$ Conf } & Interval] & Sig \\
\hline $\ln \mathrm{Popu}$ & .388 & .167 & 2.32 & .026 & .05 & .726 & $* *$ \\
\hline $\ln$ PopuDens & -.214 & .152 & -1.41 & .166 & -.52 & .092 & \\
\hline Lngdp & .153 & .169 & 0.91 & .37 & -.188 & .494 & \\
\hline PBelowpv & .016 & .011 & 1.55 & .129 & -.005 & .038 & \\
\hline Netmigra & .095 & .047 & 2.01 & .052 & -.001 & .19 & $*$ \\
\hline UnempRate & .024 & .033 & 0.74 & .465 & -.042 & .091 & \\
\hline Literacy & -.003 & .009 & -0.33 & .746 & -.022 & .016 & \\
\hline PressFreed & .005 & .013 & 0.35 & .732 & -.022 & .032 & \\
\hline AirTrans & 0 & 0 & 3.11 & .003 & 0 & 0 & $* * *$ \\
\hline GPeace & -.293 & .444 & -0.66 & .513 & -1.189 & .604 & \\
\hline subregion & .118 & .125 & 0.95 & .35 & -.134 & .369 & \\
\hline Constant & -1.734 & 3.008 & -0.58 & .568 & -7.814 & 4.346 & \\
\hline Mean dependent var & & 8.614 & & SD dependent var & & 1.641 & \\
\hline F-test & & 8.677 & & Prob $>$ F & & 0.000 & \\
\hline $\begin{array}{l}\text { Akaike crit. (AIC) } \\
* * * p<.01, * * p<.05\end{array}$ & & 159.932 & & Bayesian crit. (BIC) & & 185.545 & \\
\hline
\end{tabular}

Second, the magnitude of people (net migration) travel between countries contributes for the spread of COVID-19 to African countries. The net migration rate indicates the contribution of migration to the overall level of population change. A net migration rate of a country has positive and significant $(\beta=0.09475, \mathrm{p}=0.0 .052)$ contribution to the 
spread of COVID-19 virus to African countries at 5\% significant level. These countries with high exposure to immigration rate have high chance for the exposure to COVID-19 virus. Thus, patrolling the entry of people into a country may slow the spread of COVID-19 virus to the country.

The third significant factor for the spread of COVID-19 was the rate of internet penetration or access to internet of particular country's population. Internet penetration rate is the percentage of population with internet service access with in a given country. This factor is very amazing one for having significant and positive ( $\beta=0.0191, \mathrm{p}=0.0 .037$ ) relationship with the spread of COVID-19 virus at 5\% significant level. No one may expect this finding. Most of us usually consider good access to internet increases the access for information that may help us to reduce the spread of the virus by hearing safety measures and opting remedial actions. However, the regression result of this study shows a clue in an opposite view since access to internet contributes to the spread of COVID-19 virus. This might be true due to the existence of close contact between internet users and the devices used to access an internet such as computers, mouth, cable, desks, and sharing single internet room for many users. The virus may use these tools as one means of media for transmission and spread. As it is obvious the possibility to get access to internet service in private is very low in most African countries. As a result, many internet users may share single internet room for internet service purpose. Thus, the roles of internet might be in the contrary of our consideration if a great care is not taken like social distancing to reduce the contact with other people and self-hygiene. This analysis shall not be limited to the internet service variable. It shall goes to other similar service providers like hotels, hospitals, schools, transport services, etc., that particularly involve the interaction among people for common uses.

The fourth factor is number of passengers via airways transport. As the regression results indicate the closure of airline ways was the right remedy to reduce and alleviate the spread of COVID-19 virus during the virus outbreak. The number of passengers through airways contributes significantly and positively $(\beta=1.50, p=0.003)$ to the spread of Covid12 virus into African countries. The relationship is highly significant at $1 \%$ significant level. The first corona virus case was confirmed in Ethiopia with the person travelling to Ethiopia using Ethiopian Airlines before any corona virus infection case is reported in the country. Likewise, these countries experienced in travelling people from place to place using their own airways might have high exposure to the spread of COVID-19 than other countries do not have airways. The passengers may carry the virus easily from one location to other location. This result is very similar to net migration that playing significant role for the spread on COVID-19 virus in African countries.

Other variables not mentioned in this section but included in the model such as population density, population below the poverty line, unemployment rate, literacy rate, press freedom index, global peace index, sub-region and GDP of a country have no either positive or negative significant contribution to the spread of COVID-19 virus into African countries. And we call for future further study to investigate the contribution of these variables for the spread of COVID-19 virus in Africa.

\section{Conclusions and Recommendation}

This study was conducted to investigate factors contributing to the spread of COVID-19 virus into African countries. The analysis of data and findings of the study showed us a clue to draw the conclusion that population size, net migration rate, internet penetration rate and number of passengers via airways of particular country play a significant roles in the spread of COVID-19 virus regardless of African country's population density, population below the poverty line, unemployment rate, literacy rate, press freedom index, global peace index, subregion and GDP. It is advisable to design remedial measures and policies to control the spread of COVID-19 into African countries regarding to the country's degree of population size, net migration rate, internet penetration rate, and number of airways passengers.

\section{References}

[1] Ataguba, O. A., \&Ataguba, J. E. (2020). Social determinants of health: the role of effective communication in the COVID19 pandemic in developing countries. Global health action, 13 (1), 1788263. https://doi.org/10.1080/16549716.2020.1788263

[2] Grace Gondwe (2020). Assessing the Impact of COVID-19 on Africa's Economic Development. United Nations conference on Trade and Development, UNCTAD/ALDC/MISC/2020/3.

[3] Guadagno, L. (2020). Migrants and the COVID-19 pandemic: An initial analysis. Migration Research Series No. 60, IOM, Geneva.

[4] Jain, R., Budlender, J., Zizzamia, R., Bassier, I. (2020). The labor market and poverty impacts of covid-19 in South Africa. Cape Town: SALDRU, UCT. (SALDRU Working Paper No. 264).

[5] Kushan Tharuka Lulbadda, Dhanushka Kobbekaduwa and Malika Lakmali Guruge, Clinical Epidemiology and Global Health, https://doi.org/10.1016/j.cegh.2020.09.004.

[6] Marois G, Muttarak R, Scherbov S (2020) Assessing the potential impact of COVID-19 on life expectancy. PLoSONE $15 \quad$ (9): $\quad 0238678$. https://doi.org/10.1371/journal.pone.0238678

[7] Sirkeci, I., \& Yucesahin, M. M. (2020). Coronavirus and Migration: Analysis of Human Mobility and the Spread of Covid-19. Migration Letters, 17 (2), 379-398. https://doi.org/10.33182/ml.v17i2.935

[8] Skeldon, R. (2018). International migration, internal migration, mobility and urbanization: Towards more integrated approaches. Migration Research Series No. 53, IOM, Geneva. 
[9] WHO (2020). Available on https://www.who.int/directorgeneral/speeches/detail/who-director-general-s-openingremarks-at-the-media-briefing-on-covid-19---11-march-2020, accessed on September 24, 2020.

[10] Worldometers (2020) Accessed on sep 17/2020 https://www.worldometers.info/coronavirus/?utm_campaign= homeAdvegas1?\#countries
[11] Zhu, Y., Xie, J., Huang, F. \& Cao, L. (2020). Association between short-term exposure to air pollution and COVID-19 infection: Evidence from China. Sci. Total Environ. 727, https://doi.org/10.1016/j.scitotenv.2020.138704. 